\title{
JUURNAL.RU
}

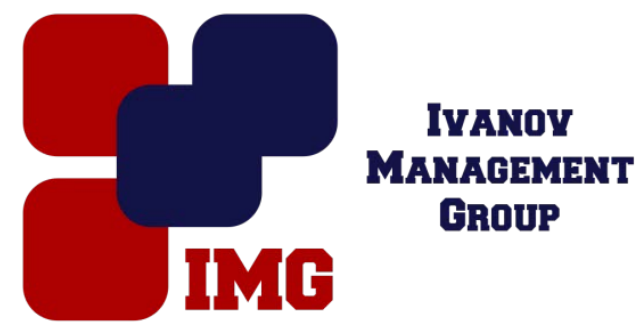

Ермошенко Н.С. ЮжноРоссийский Государственный Университет имени М.И.Платова Новочеркасск, Россия

doi: 10.18411/lj-31-03-2017-2-05

idsp 000001:lj-31-03-2017-2-05

\section{Современные методы обследования зданий городской застройки}

\section{Аннотация}

В современном строительстве при реконструкции и эксплуатации зданий и сооружений городской застройки требуется определение их оценки технического состояния с учетом природных и техногенных воздействий, в том числе ограждающих, ливнеотводящих и инженерных коммуникаций.

Ключевые слова: методы, конструкции, обследование, городская застройка, природные и техногенные воздействия, этапы обследования, оценка технического состояния объекта

Выполнение инженерных и изыскательных работ при выполнении обследования направлены на определение технического состояния всего здания или на обследование его отдельных конструкций. Для несущих элементов и грунтов основания является главной частью по обоснованию их технического состояния его кровли и инженерных сетей.

Обследование зданий и сооружений выявляет дефекты и отражает реальное состояние элементов конструкций. Анализ результатов изысканий позволяет судить о целесообразности ремонта или реконструкции, а также определяет меры по устранению дефектов и усилению несущих элементов, в том числе повышение в дальнейшем эксплуатационной нагрузки.

При нарастающих деформациях в зданиях и сооружениях, а так же в их конструкциях, деформации выражены в виде трещин. Поэтому так велико значение инженерного обследования, которое определяет степень опасности объекта, возможность его эксплуатации в определенный период времени, а так же его влияние на окружающие городские постройки.

При определении целесообразности капитального строительства или реконструкции определяют качество строительных материалов ограждающей конструкции. Например, здания и сооружения, у которых они выполнены из силикатного кирпича и простоявшие более зо лет необходимо включать в список аварийных, так как состав силикатного кирпича имеет срок эксплуатации до 20-25 лет, что влечет за собой изучение множества вопросов по данному объекту и 
необходимость рассмотрения всех фактороввключая экономический и экологосоциальный.

Для принятия целесообразного решения относительно того или иного объекта необходимо руководствоваться детальным инструментальным обследованием здания. На основе его составляются: характеристика объекта;перечень дефектов и деформаций; а также рекомендации по устранению дефектов и выбору оптимального режима эксплуатации объекта.

Полное инструментальное обследование зданий выполняется:

- при потере проектной документации или в процессе оформления технического паспорта на самовольное строение

- при разработке проекта реконструкции или капитального ремонта для определения основного круга задач

- после аварии, катастрофы, ЧС - экспертиза позволяет определить уровень повреждений и оценить возможность дальнейшей эксплуатации объекта

- перед возобновлением работ на объектах незавершённого строительства

- плановое обследование не позже двух лет со сдачи объекта

Обследование зданий и сооружений делится на три основных этапа: подготовку, визуальный осмотр и детальное обследование.При этом следует применятьтепловизор. С его помощью можно обнаружить дефекты, выполнить анализ неисправностей в конструкциях здания. Прибор фиксирует изображение в инфракрасных лучах.

Для каждого прибора необходимо использовать метод по проведению измерений, учитывая его погрешности.

\section{Литература}

1. Оценка надежности зданий и сооружений по внешним признакам. Добромыслов А.Н. 2008г

2. Техническая эксплуатация зданий и сооружений. Комков В.А. 2007г. 